\title{
Effect of exogenous leukemia inhibitory factor on reparative regeneration of the peripheral nerve in mice
}

\author{
Labunets I. F. ${ }^{1}$, Demydchuk A. S. ${ }^{2}$, Shamalo S. M. ${ }^{2}$, Utko N. O. ${ }^{1}$, Rodnichenko A. E. ${ }^{1}$, Rymar S. Yu. ${ }^{1}$, \\ Chaikovsky Yu. B. ${ }^{1,2}$, Butenko G. M. ${ }^{1}$ \\ ${ }^{1}$ State Institute of Genetic and Regenerative Medicine of the National Academy of Medical Sciences of Ukraine, Kyiv, Ukraine \\ ${ }^{2}$ O. O. Bogomoletz National Medical University of Ministry of Health of Ukraine, Kyiv, Ukraine \\ e-mail: irina_labunets@ukr.net
}

\section{ABSTRACT}

The role of trophic and growth factors in the regeneration of the damaged peripheral nerve is known. The leukemia inhibitory factor (LIF) exhibits properties not only of the polyfunctional cytokine, but also the neurotrophic factor. Regeneration of the peripheral nerve is impaired during oxidative stress in the area of injury.

The PURPOSE of the work was to investigate the effect of recombinant human LIF (rhLIF) on the efficacy of reparative regeneration of the sciatic nerve.

MATERIALS AND METHODS. Adult male FVB/N mice were divided into the following groups: sham-operated; trauma (neurotomy) of the right sciatic nerve; nerve injury and subcutaneous injection of rhLIF at a dose of $1 \mu \mathrm{g}$ per animal daily from the third day after the nerve injury. The study was conducted 4 weeks after the injury. At morphometry, the density of nerve fibers in distal nerve segments after impregnation with nitric oxide silver was evaluated. The motor function was evaluated in the "open field» test by the number of crossed squares, and in footprint test by the distance between the extreme toes of the right foot. In the area of muscle injury, the content of malondialdehyde, superoxide dismutase, catalase, glutathione peroxidase, and glutathione reductase was estimated.

RESULTS. The total number of nerve fibers in the distal segment of the nerve of mice with trauma and injection of rhLIF is greater ( $p<0.05)$ than in mice with only nerve injury and does not differ from sham-operated animals. Horizontal motor activity in mice with nerve injury is lower $(p<0.05)$ than in sham-operated and cytokine injected mice. The distance between the extreme toes of the sham-operated mice is greater $(p<$ $0.05)$ than in mice with nerve injury, as well as injuries and injections of rhLIF, but after the injection of cytokine, the rates are higher $(p<0.05)$ than in the group of mice without it. After the injury, the content of malondialdehyde and catalase activity increases in muscle tissue, while the activity of glutathione reductase decreases $(p<0.05)$. Under the influence of $r h L I F$, the parameters change to the values of sham-operated mice, and, in addition, the activity of the glutathione peroxidase is significantly increased.

CONCLUSIONS. Injection of rhLIF to mice with a sciatic nerve injury promotes a more complete restoration of the structural organization of the damaged nerve and improves the motor function of the injured limb. At the same time, the balance between the factors of oxidative stress and antioxidant system is improved in the muscle tissue in the area of the nerve injury.

KEYWORDS: leukemia inhibitory factor; sciatic nerve; neural tissue regeneration; antioxidant enzymes; motor function

The relevance of the problem of peripheral nerve injuries is due to the prevalence of this pathology, inadequate effectiveness of traditional methods of treatment and high disability of patients [1, 2]. New approaches aimed at improving the efficiency of damaged peripheral nerve regeneration include the use of microsurgical techniques, drugs, electrostimulation, cell technologies with the transplantation of stem cells of various genesis in the site of injury [2-5]. Recently, a great attention has been paid to the development of pathogenetic approaches 
to accelerating the regeneration of injured peripheral nerve, based on the study of its mechanisms, in particular the study of the significance of microenvironment factors for myelination and axonal neuronal growth [6].

The participation of various cytokines, trophic and growth factors, which are synthesized by different types of cells (macrophages, fibroblasts, Schwann cells), is known both in the processes of degeneration and regeneration of damaged peripheral nerves $[3,7,8,9]$. Thus, in the reparative regeneration of peripheral nerves, there is shown the efficacy of the brain-derived neurotrophic factor (BDNF), stromal cell-derived factor (SDF-1), nerve growth factor (NGF), etc., which are injected into the trauma site per se, using plasmid constructs, stem cells of various genesis, which synthesize them $[2,3,10]$.

Among the variety of cellular factors with a stimulating effect on reparative regeneration of peripheral nerves, our attention was attracted by the leukemia inhibitory factor (LIF) from the family of interleukin-6 (IL-6), which exhibits properties not only of the polyfunctional cytokine, but also of the neurotrophic factor [11, 12]. In particular, it has been established that LIF prevents demyelization, is a growth factor for neural stem cells (NSCs), Schwann cells and axons, reduces their apoptosis, increases the lifetime of motor neurons. The enhancement of LIF expression in the Schwann cells was demonstrated in the first hours after the injury, so this cytokine is a factor of nerve injury [13]. However, the effect of cytokine on restoration of the functional state of the limb after damage to the peripheral nerve remains poorly understood.It is also important to study possible changes of antioxidant defense activity in tissues of injured limbs under the influence of LIF, since regeneration of the damaged peripheral nerve is impaired in conditions after traumatic oxidative stress $[14,15]$.

Therefore, the work was aimed at studying the effect of the injection of recombinant human LIF (rhLIF) on the recovery of the structure of the damaged sciatic nerve and the motor function of the injured limb, as well as the assessment of the changes in the activity of oxidative stress and antioxidant activity in its muscle tissue.

\section{MATERIALS AND METHODS}

Animals. The study was conducted on 6-8 months-old male FVB/N mice $(n=24)$. Animals were obtained from the vivarium of the State Institute of Genetic and Regenerative Medicine NAMS of Ukraine. Mice were kept under standard conditions (free access to water and food) with fixed light/dark regimen (12:12). Biological material for experiments was obtained from the animals in the morning hours under ether anesthesia. All work was carried out in compliance with the Law of Ukraine "On the Protection of Animals from Cruelty» (2006), «European Convention for the Protection of Vertebrate Animals Used for Experimental and Other Scientific Purposes» (Strasbourg, 1986).

Experimental animal groups. Mice were divided into the following groups: 1 - sham-operated control (mobilization of the right lateral nerve without neurotomy); 2 - injury of the sciatic nerve (right nerve transection at the middle third) and injection of $0.9 \%$ saline [1]; 3 - trauma of the right sciatic nerve and subcutaneous injection of rhLIF at a dose of $1 \mu \mathrm{g}$ per animal daily from the third day after the nerve injury [16]. It has been shown that rhLIF exhibits its biological activity not only to human cells, but also to mice cells and after injection interacts with the receptors to this cytokine on the cells of the nervous system [17]. Each experimental group consisted of 8 animals. The studies were conducted for 28 days after surgery. All surgical interventions were performed under avertine anesthesia ( $2.5 \%$ solution, $125 \mathrm{mg} / \mathrm{kg}$, intraperitoneally).

Morphological study of the sciatic nerve. Fragments of the right sciatic nerve that contained regenerative neuromas with proximal and distal segments were fixed in a $10 \%$ solution of neutral formalin for 24 hours. After washing, cryostat sections were made, which were impregnated with silver nitrate by the rapid method of impregnating elements of the peripheral nervous system [18]. A part of the sections was stained with azure II-eosin to study the structure of the connective tissue.

The histological preparations were studied and photographed using a microscope BX 51, connected to a digital camera C 3040 Z00M (Olympus, Japan) and a computer. For morphometric analysis, a standard eyepiece and the UTHSCSA Image Tool for Windows (v. 2.00) software were used. The number of nerve fibers per $1 \mathrm{~mm}^{2}$ cross-section of the nerve was measured.

The motor function of the injured limb was estimated in the open field test on the number of crossed squares (horizontal motor activity), as well as in footprints test at a distance $(\mathrm{mm})$ between the extreme toes of the foot of the injured limb [19]. As we have established, the joint use of these techniques to evaluate the motor function of experimental mice hind limbs enables to reliably estimate the effectiveness of the motor function restoration after a sciatic nerve injury.

Activity of oxidative stress and antioxidant defense factors in muscle tissue of the injured area. The content of malondialdehyde (MDA), as a marker of oxidative stress in the muscle tissue homogenates, was determined by the Uchiyama method [20] with minor modifications. The principle of this method is to determine the staining intensity during the reaction between MDA and thiobarbituric acid (TBA) under acidic condition at high temperature. As a result of the reaction, a complex containing one MDA molecule and two TBA molecules is formed and has a specific absorption spectra with a maximum at a wavelength of $535 \mathrm{~nm}$.

The activity of antioxidant enzymes was evaluated using microplate spectrophotometer $\mu$ Quant ${ }^{\mathrm{TM}}$ (Bio-Tek, USA) in supernatants of muscle tissue homogenates of experimental animal groups $(10,000 \mathrm{~g}$ for 20 min) [21]. Thus, to study the superoxide dismutase (SOD) activity, a method based on the ability of the enzyme to suppress the autoxidation reaction of adrenalin (Fluka, Germany) to adrenochrome at pH 10.2 was used; SOD activity was evaluated in arbitrary units per $1 \mathrm{mg}$ of protein per 1 minute. The activity of catalase was determined from the kinetics of $\mathrm{H}_{2} \mathrm{O}_{2}$ decay (Riedel-deHaën, Germany) and expressed in micromoles of $\mathrm{H}_{2} \mathrm{O}_{2}$ decomposed per $1 \mathrm{mg}$ of protein per $1 \mathrm{~min}$. The activity of glutathione peroxidase and glutathione reductase was measured by NADPH decreasing using Glutathione Reductase Assay Kit (Sigma, USA) and expressed in nanomoles of oxidized NADPH per $1 \mathrm{mg}$ of protein per $1 \mathrm{~min}$. The protein content in the muscle tissue was measured by Lowry method.

Statistical analysis. The statistical analysis of the results was carried out using the parametric statistical methods (Student's t-test) [22]. The difference between the investigated parameters was considered statistically significant at a value of $p<0.05$. Statistica 7.0 software (StatSoft Inc., USA) was used for statistical analysis.

\section{RESULTS AND DISCUSSION}

MORPHOLOGICAL STUDY OF THE INJURED SCIATIC NERVE STRUCTURE IN ANIMIALS OF EXPERIMIENTAL GROUPS. The results of the study of the regenerative neuroma and the distal segment of the sciatic nerve in experimental animal groups are shown in Fig. 1, A-D. It has been established that after the intersection of the nerve in animals, a regenerative neuroma, which includes nerve fibers, blood vessels, cells (mainly fibroblasts), collagen fibers and the main substance of the connective tissue, is formed. In animals with a nerve injury without rhLIF application, there is formation of a dense connective tissue scar, which mostly has collagen fibers and also there are zones with low number of vessels. Nervous fibers are arranged irregularly: one part has a longitudinal and the other - oblique or transverse course relative to the longitudinal axis of the nerve (Fig. 1, A). Following the injection of rhLIF into animals with a nerve injury, another structure of the neuroma is observed: its connective tissue is less dense due to the predominance of cellular elements and the absence of zones with low number of vessels. Nervous fibers are more ordered, mostly linearly (Fig. 1, C). 

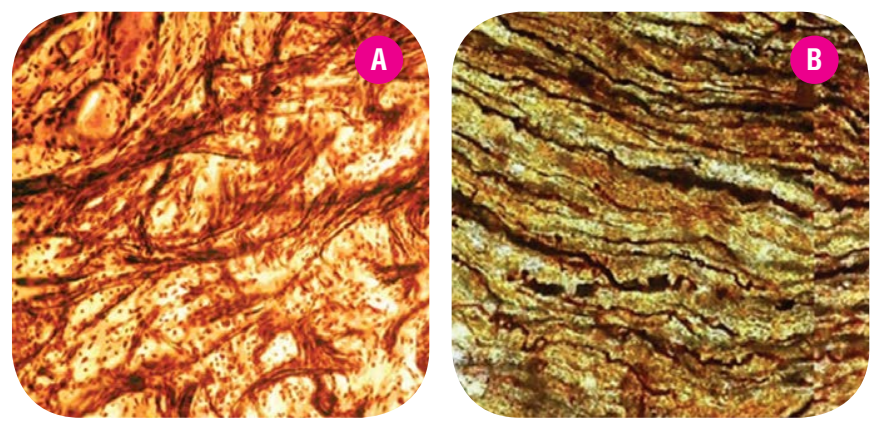

NERVE INJURY
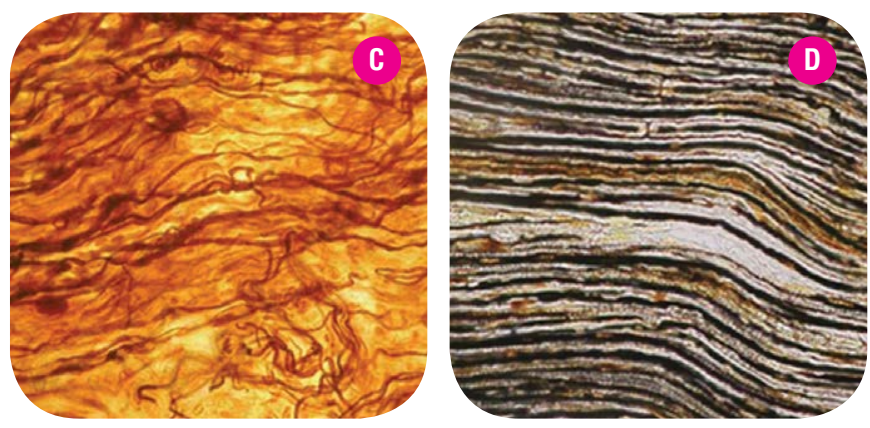

NERVE INJURY +rhLIF

Fig. 1. Microphotographs of the histologic preparations of the sciatic nerve of FVB/N mice. Effect of injection of rhLIF on the structure of the damaged nerve. $A, C$ - regenerative neuroma; $B, D$ - distal segment of the nerve. Silver nitrate impregnation, $\mathrm{x} 400$.

After the nerve injury without rhLIF application, the nerve fibers growth into the distal segment of the nerve (Fig. 1, B) is disrupted: a small amount of newly formed nerve fibers is found. Similar to the site of the neuroma, they are arranged in a disordered manner, characterized by hyper- or hypo-impregnation symptoms. The injection of rhLIF greatly affects the regeneration of nerve fibers in the distal segment of the injured nerve: the newly formed nerve fibers have linear course, characterized by uniform impregnation, their number is much higher than that of the animals in the group without rhLIF application (Fig. 1, D).

In the morphometric analysis, it was found that the density of nerve fibers in the distal segment of the sciatic nerve of the injured mice receiving rhLIF was greater $(p<0.05)$ than in the mice with only a nerve injury and does not differ from the indicator in sham-operated animals (Fig. 2).

THE MOTOR FUNCTION OF THE HIND LIMBS. It has been found that in mice with nerve injury, the number of crossed squares in the open field test is significantly lower than in the groups of sham-operated mice and animals with nerve injury with rhLIF application (Fig. 3, A). In the «footprint» test, it was found that the distance between the extreme toes of the traumatized limb in the mice of the control group is greater than in mice with nerve injury or injury with simultaneous injection of rhLIF (Fig. 3, B). However, in experimental mice receiving rhLIF, the values were higher $(p<0.05)$ than in mice with nerve injury only.

ACTIVITY OF OXIDATIVE STRESS AND ANTIOXIDANT DEFENSE FACTORS IN MUSCLE TISSUE IN THE INJURED AREA. We found a significant increase in the malondialdehyde content in muscle tissue in the area of injury compared with the control group (Table 1). In the muscle tissue of animals with a sciatic nerve injury, a significant increase in the activity of catalase is observed, while the activity of glutathione reductase decreases. After injection of rhLIF to experimental animals, there is a

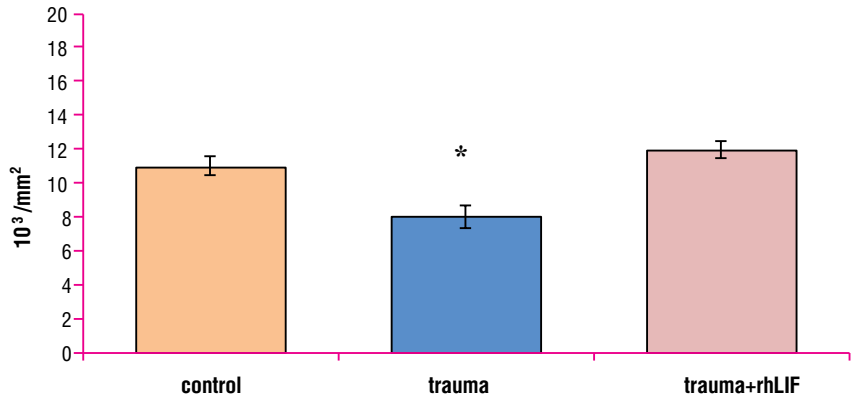



A Fig. 2. The number of nerve fibers per $1 \mathrm{~mm}^{2}$ of the cross section of the distal segment of the sciatic nerve under the influence of rhLIF. Note: ${ }^{*}-p<0.05$ compared to sham-operated animals
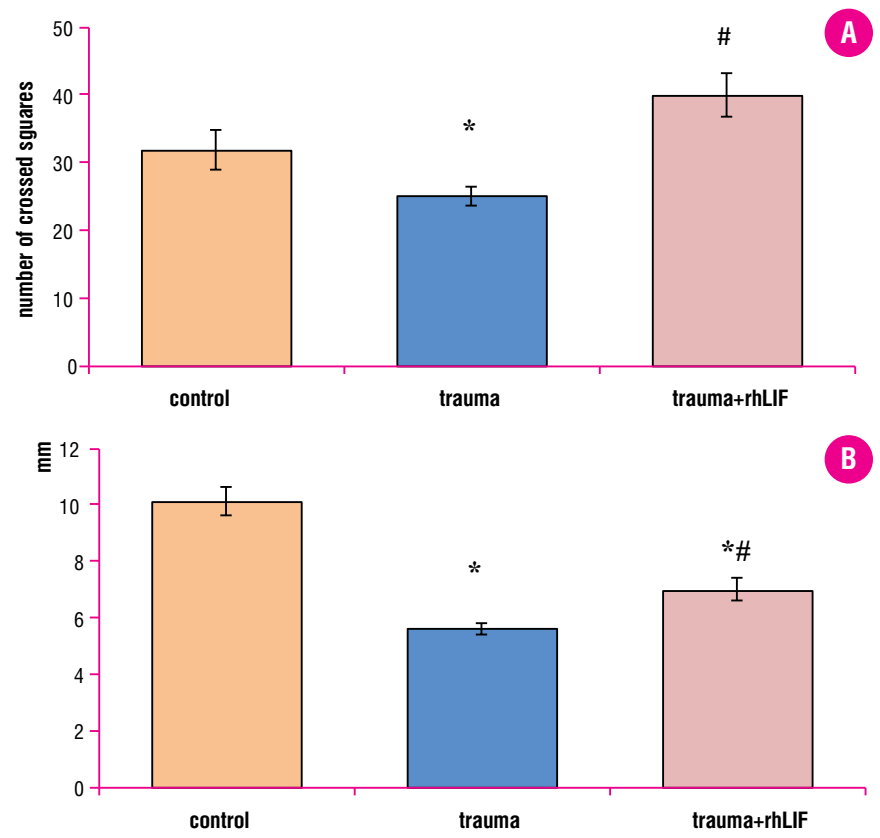

人

Fig. 3. Index of motor function after the injection of rhLIF in mice with the sciatic nerve injury: A - horizontal motor activity in open field test; $B$ - the distance between the extreme toes of the foot in footprint test. Notes: ${ }^{*}-p<0.05$ compared to sham-operated animals; $\#-p<0.05$ compared to nerve injury.

significant reduction in the MDA content to the level of sham-operated animals and a significant increase in the activity of the glutathione peroxidase and glutathione reductase.

Thus, the injection of rhLIF to adult mice with sciatic nerve injury promotes a more complete restoration of the structural organization of the damaged nerve and improves the motor function of the injured limb. In this case, the muscle tissue in the area of the injury improves the balance between the factors of oxidative stress and antioxidant protection.

The possibility of the neuroprotective effect of LIF in the nervous system injury was investigated by the authors mainly at multiple intraperitoneal injection $[12,23]$. According to our preliminary data, this method of rhLIF injection into mice leads to an increase in the number of nerve fibers in the distal segment of the injured nerve. However, in this work, we have used long-term subcutaneous injection of rhLIF in the area of the sciatic nerve injury [16]. Such an approach can contribute to the maintenance of a sufficiently stable cytokine content at the site 


\begin{tabular}{|c|c|c|c|}
\hline \multirow{2}{*}{ INDEX } & \multicolumn{3}{|c|}{ EXPERIMENTAL GROUP } \\
\hline & SHAM-OPERATED CONTROL & NERVE INJURY & NERVE INJURY + rhLIF INJECTION \\
\hline Malondialdehyde (nmol/mg) & $4.6 \pm 0.3$ & $9.4 \pm 0.5^{\star}$ & $5.1 \pm 0.3^{\#}$ \\
\hline Superoxide dismutase (units/mg•min) & $7.4 \pm 0.5$ & $6.7 \pm 0.4$ & $6.4 \pm 0.6$ \\
\hline Catalase $(\mu \mathrm{mol} / \mathrm{mg} \bullet \mathrm{min})$ & $1.4 \pm 0.3$ & $2.1 \pm 0.4^{*}$ & $2.0 \pm 0.5^{\star}$ \\
\hline Glutathione peroxidase $(\mathrm{nmol} / \mathrm{mg} \bullet \mathrm{min})$ & $2.5 \pm 0.2$ & $2.9 \pm 0.3$ & $3.5 \pm 0.3^{*}$ \\
\hline Glutathione reductase (nmol/mg•min) & $8.1 \pm 0.4$ & $6.8 \pm 0.3^{*}$ & $9.6 \pm 0.5^{\#}$ \\
\hline
\end{tabular}

Notes: * $-p<0.05$ compared to sham-operated animals; \# $-p<0.05$ compared to nerve injury.

of the injury, which, according to Ostasov [11], is important for the development of regenerative processes in it. Indeed, we have observed not only the growth of the number of nerve fibers in the distal segment of the injured sciatic nerve, but also the improvement of the structure of the regenerative neuroma. In mice with the nerve injury receiving rhLIF, positive changes in the structure of the damaged nerve can be attributed to the effect of cytokine on axons of neurons, expression of NGF, and anti-apoptotic effect on nerve cells $[11,12]$. We do not exclude that these mice also have positive changes in the functioning of the motor neurons of the spinal cord.

As Petrova notes [3], the efficiency of the sciatic nerve regeneration after injury largely depends on the state of the motor neurons of the spinal cord. In the model of spinal cord injury, it has been shown that in this organ LIF enhances the proliferation of NSCs and promotes their predominant differentiation into neuronal direction, improves the survival of the generated and functioning motor neurons, and stimulates the growth of neurites [11, $24,25]$. It has been established that in the motor neurons of the spinal cord there is LIF receptor (LIFR), and knockout mice (LIFR ${ }^{--}$) exhibit $40 \%$ reduction of motor neurons [11]. The possibility of LIF retrograde transport, like NGF, from nerve terminals to the bodies of sensory neurons in the spinal ganglia as a survival factor is proved [12]. After an injury of the peripheral nerve, LIF is retrogradely transported in motor neurons, where it serves as a survival factor and reduces the loss of neurons after a neurotomy [26]. LIF deficiency leads to changes not only in nerve terminals in striated muscle, but also in neuromuscular junctions, which are important for retrograde transport of other motor neuron survival factors, in particular, the ciliary neurotrophic factor (CNTF) [27]. In our further work, we plan to investigate the structure of the motor neurons of the spinal cord in animals with sciatic nerve injury receiving rhLIF.

The positive effect of LIF on functioning of neurons and on glial cells, in particular, myelin synthesizers is established. So, after the injection of the cytokine, an increase in the proliferation of these cells and their synthesis of myelin, as well as remyelination of axons of neurons after injury are observed $[23,28]$. In our studies, improving the motor function of the injured limb in experimental mice indirectly indicates the stimulation of myelin nerve fibers formation after the injection of rhLIF.

However, according to Ostasov [11], the importance of LIF in the pathology of the nervous system and the development of regenerative processes in it is associated not only with the influence of the cytokine on the development and function of the neurons in the motor system, but is also determined by its properties as an integrative molecule between nervous and immune systems. In particular, LIF detects chemokine function for macrophages, improving their migration to the peripheral nerve injury site [29]. On the contrary, in LIF-knock-out mice, macrophage infiltration of the damaged peripheral nerve is significantly inhibited. The chemokine function is specific for LIF, since macrophages do not respond to other neuropathic cytokines such as CNTF, IL-6, IL11 , and oncostatin $M$. The importance of the chemokine function for LIF is due to the fact that macrophages are key cells in the damaged nerve that phagocyte products of myelin disruption $[15,30]$. These cells pass through the blood-nerve barrier during the first 2-3 days after nerve injury, infiltrate it and synthesize proinflammatory cytokines (IL-1 $\beta$, TNFa) [9]. Macrophages play a critical role in regeneration of damaged peripheral nerves by influencing the proliferation of neurolemmocytes and dissolving myelin lipids for their reutilization during regeneration. The changes in the phenotype of macrophages from proinflammatory to anti-inflammatory in the dynamics of degeneration and subsequent regeneration of the peripheral nerve are possible [8]. Taking into account the anti-inflammatory properties of LIF [12], we do not exclude the possibility of switching the pro-inflammatory phenotype of macrophages to anti-inflammatory effects under the influence of rhLIF in our study.

According to our data, in the mechanism of rhLIF stimulating effect on regeneration of the damaged sciatic nerve its antioxidant properties may also be significant. Oxidative stress is the result of accelerated formation of free radicals, reactive oxygen species (ROS), as well as changes in the activity of key antioxidant enzymes - SOD, catalase, glutathione peroxidase [21]. It is shown that at the development of oxidative stress LIF, on the one hand, reduces the level of ROS, MDA, on the other hand increases the activity of SOD [31]. In our work, we investigated the content of the factors of oxidative stress and antioxidant defense in the muscle tissue, in which impairment of not only the trophic function of the injured nerve, but also of the neuromuscular contact is possible. We found the inhibitory effect of rhLIF on the high content of MDA in muscle tissue. The lack of activation of SOD in the tissue of animals receiving the cytokine can be partly explained by the terms of the study, since the activation of this enzyme is the first link of antioxidant defense, which usually occurs at the early stages after injury. However, we managed to establish glutathione peroxidase activation, under the influence of rhLIF, which after SOD impact controls breakdown of $\mathrm{H}_{2} \mathrm{O}_{2}$ to $\mathrm{H}_{2} \mathrm{O}$, along with catalase. The reactivation of glutathione reductase after the injection of LIF is also significant. It is responsible for the reduction of oxidized glutathione in the reaction that catalyzes glutathione peroxidase. The result of such biochemical changes under the influence of rhLIF can be the improvement of metabolic processes in the denervated muscle tissue. 


\section{CONCLUSION}

1. Exogenous rhLIF stimulates reparative regeneration of damaged sciatic nerve and improves motor activity of the injured limb in mice.

2. In the mechanism of positive morpho-functional changes of the damaged sciatic nerve, the influence of cytokine on the factors of oxidative stress and antioxidant protection is important.

3. Results may be useful in cell technologies that use LIF as a microenvironment factor, as well as in the search of drugs that increase the synthesis of this cytokine in the area of the injury.

\section{REFERENCES}

1. Chaikovsky YuB, Deltsova OI, Gerashchenko SB. Mizhtkaninni vzaemodii periferiynogo nerva v normi ta patologii [lnterstitial interactions of peripheral nerve in norm and pathology]. Ivano-frankivs'k: Lileya - Ivano-Frankivsk: Lileya-HB, 2009. 408 p. [In Ukrainian]

2. Butenko GM, Chaikovsky YuB. Stovburovi klitini i problema vidnovlennya periferichnikh nerviv [Stem cells and the problem of recovery of peripheral nerves]. Mistetstvo likuvannya - Art of treatment. 2013; 101(5): 56-58. [In Ukrainian]

3. Petrova ES. Primenenie stvolovykh kletok dlya stimulyatsii regeneratsii povrezhdennogo nerva [The use of stem cells to stimulate regeneration of a damaged nerve]. Tsitologiya - Cytology. 2012; 54(7): 525-540. [In Russian]

4. Tsymbaliuk YuV, Malisheva TA, Rudenko SO, et al. Primenenie stvolovykh kletok dlya stimulyatsii regeneratsii povrezhdennogo nerva [Morphological changes of peripheral nerves after neuroraphy and electrostimulation]. Morfologiya - Morphology. 2013; 7(4): 78-85. [In Russian]

5. Vasyliev $R$, Rodnichenko A, Shamalo $S$, et al. Effects of neural crest-derived multipotent stem cells on regeneration of an injured peripheral nerve in mice. Neurophysiology. 2015; 47(1): 80-83.

6. Casey D, Dipollina J, Fornaro M. Effects of enhancing neuritogenesis and peripheral nerve regeneration. Neural Regen Res. 2016; 11(2): 220-221. Available: https:// doi:10.4103/1673-5374.177717.

7. Madduri S, Gander B. Schwann cell delivery of neurotrophic factors for peripheral nerve regeneration. J Peripheral Nervous System. 2010; 15: 93-103.

8. RotshenkerSh. Wallerian degeneration: the innate-immune response to traumatic nerve injury. J Neuroinflam. 2011; 8: 109-114. Available: http:/wwwjneuroinflammation. com/content/8/1/109.

9. Dubovy $P$, Jancalek R, Kubek T. Role of inflammation and cytokines in peripheral nerve regeneration. Int Rev Neurobiol. 2013; 108: 173-200.

10. Strafun SS, Gaiovych VV, Savosko SI. Ul'trastrukturna otsinka vidnovlennya travmovanogo sidnichnogo nerva pri autoplastitsi yogo velikikh defektiv u shchuriv v eksperimenti [Ultrastructural evaluation of recovery of injured sciatic nerve at autografting of it's large defects in rats: Experimental study]. Ukraïns'kiy neyrokhirurgichniy zhurnal - Ukrainian Neurosurgical Journal. 2014; 4: 50-54. [In Ukrainian]

11. Ostasov P. Houdek Z, Cendelin J, et al. Role of leukemia inhibitory factor in the nervous system and its pathology. Rev Neurosci. 2015; 26(4): 443-59.

12. Nicola N, Babon J. Leukemia inhibitory factor. Cytokine Growth Factor Rev. 2015; 26: 533-544.

13. Dowsing B, Romeo R, Morrison W, Dowsing B. Expression Of leukemia inhibitory factor in human nerve following injury. J Neurotrauma. 2001; 18(1): $1279-1287$.

14. Naik A, Tandan S, Dudhgaonkar S, et al. Role of oxidative stress in pathophysiology of peripheral neuropathy and modulation by N-acetyl-L-cysteine in rats. Eur J Pain. 2006; 10(7): 573-579.

15. DeFrancesko-Lisowitz A, Lindborg J, Niemi J, et al. The neuroimmunology of degeneration and regeneration in peripheral nervous system. Neuroscience. 2015; 302: 174-203.

16. Labunets IF, Rymar SYu, Chaikovsky YuB, Butenko GM. Sposib modelyuvannya stimulyatsiï regeneratsiï ushkodzhenikh periferichnikh nerviv: patent na korisnu model' [A method of simulating of stimulation the regeneration of damaged peripheral nerves: utility model patent]. Patent \# 114550 (UA): MPK G09B23/28. [In Ukrainian]

17. Layton $M$, Lock $P$, Metcaff $D$, et al. Cross-species receptor binding characteristics of human and mouse leukemia inhibitory factor suggest a complex binding interaction. J Biol Chem. 1994; 2690: 17048-17055.

18. Kolomytsev AK, Chaikovsky YuB, Tereshchenko TL. Bystryy metod impregnatsii azotnokislym serebrom elementov perifericheskoy nervnoy sistemy, prigodnyy dlya parafinovykh $\mathrm{i}$ tselloidinovykh srezov [A rapid method of impregnating by silver nitrate elements of the peripheral nervous system, suitable for paraffin and celloidin sections]. Arkh anat. - Anatomy archive. 1981; 8: 93-96. [In Russian]

19. Labunets IF, Demydchuk AS, Shamalo SM. Sposib otsinki v eksperimenti efektivnosti vidnovlennya rukhovoï funktsiï nizhn'oï kintsivki pislya ushkodzhennya periferichnogo nerva: patent na korisnu model' [The method of evaluation in the experiment of the effectiveness of restoring the motor function of the lower limb after damage to the peripheral nerve: utility model patent]. Patent \#113678 (UA): MPK G09B 23/28. [In Ukrainian]

20. Uchiyama M, Mihara M. Determination of malonaldehyde precursor in tissues by thiobarbituric acid test. Anal Biochem. 1978; 86(1): 271-278.

21. Muradian Kh, Utko N, Mozzhuknina T, et al. Pair-wise linear and 3D nonlinear relationships between the liver antioxidant enzyme activities and the rate of body oxygen consumption in mice. Free Radic Biol Med. 2002; 33: 1736-1739.

22. Lakin GF. Biometrics. Higher School, Moscow, 1990. 352 p.

23. Deverman $B$, Patterson $P$. Exogenous leukemia inhibitory factor stimulates oligodendrocyte progenitor cell proliferation and enhances hippocampal remyelination. J Neurosci. 2012; 32(6): 2100-2109.

24. Johansson C, Momma S, Clake D. Identification of neural stem cell in the adult mammalian central nervous system. Cell. 1999; 96(1): 25-34.

25. $L i Y$, Zang $D$. The neuron regrowth is associated with the proliferation of neural precurcor cells after leukemia inhibitory factor injection following spinal cord injury in mice. PLOS ONE. 2014. Available: https://doi.org/10.1371/journal.pone.0116031.

26. Curtis $R$, Scherer S, Somogyi $R$, et al. Retrograde axonal transport of LIF is increased by peripheral nerve injury: correlation with increased LIF expression in distal nerve. Neuron. 1994; 12: 191-204.

27. Holtmann B, Weise $S$, Samsam M, et al. Triple knock-out of CNTF, LIF and CT-1 defines cooperative and distinct roles of these neurotrophic factors for motoneuron maintenance and function. J Neurosci. 2005; 25: 1778-1787.

28. Razavi S, Mardani M, Kazemi M, et al. Effect of leukemia inhibitory factor on the myelinogenic ability of Schwann-like cells induced from human adipose-derived stem cells. Cell Mol Neurobiol. 2013; 2: 283-290. 
29. Sugiura Sh, Lahav $R$, Han J, et al. Leukemia inhibitory factor is required for normal inflammatory responses to injury in the peripheral and central nervous systems in vivo and is chemotactic for macrophages in vitro. Eur J Neurosci. 2000; 12: 457-466.

30. Keifer $R$, Kieseier B, Stoll G, et al. The role of macrophages in immune-mediated damage to the peripheral nervous system. Prog Neurobiol. $2001 ; \mathbf{6 4 ( 2 ) : ~ 1 0 9 - 1 2 7 . ~}$

31. Xu Jing, Li Zhigui, Xu Pengjuan, et al. Protective effects of leukemia inhibitory factor against oxidative stress during high glucose-induced apoptosis in podocytes. Cell stress and chaperons. 2012; 17: 485-493.

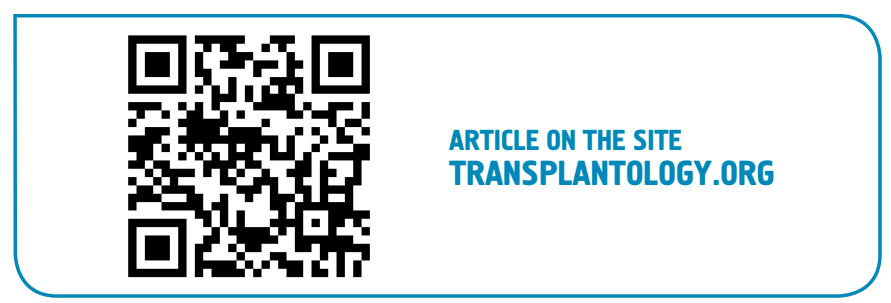

The authors indicate no potential conflicts of interest.

Received: September 13, 2017

Accepted: November 30, 2017 